\title{
The North Korean Factor in East Asian Regional Security
}

\author{
Jaebum Kim
}

Published online: 3 September 2013

(C) CEEUN 2013

\begin{abstract}
This paper first examines briefly the current security environment in East Asia and then identifies the North Korean factor in regional security. It later reviews the implications of this factor in a broader context, especially in relation to the overarching theme of the conference: "East Asian Regional Integration and the US Role". It specifically attempts to highlight three major aspects of the topic of Session I: "Political and Security Co-operation in East Asia". They are (1) the issues of status quo and national interest, (2) the relationship between regional integration and national unification, and (3) strengthening and expanding PRCJapan-ROK nuclear and space co-operation to include other states in the region and other fields of co-operation. It finally reaches the conclusion that, while the role of the United States should remain formidable and even essential for East Asian regional security and integration, the North Korean factor requires closer co-ordination and concerted efforts by all the powers concerned, both global and regional, as well as both big and small, preferably including Pyongyang herself. In the final analysis, the regional security could be better promoted by seeking synergy effects of regional integration and reunification of divided nations. As regional integration progresses so does national unification and vice versa. Each and every problem has a solution if its stakeholders approach it in a broader context, with farther-sighted visions, and in such a way as to exchange their positions with one another. More judicious prioritization of issues is required for each stakeholder.
\end{abstract}

Keywords East Asia · Regional security · North Korea · Integration · Unification · Trilateral co-operation

\section{J. $\operatorname{Kim}(\bowtie)$}

International Policy Studies Institute, Policy Commissioner, Korean Council on Foreign Relations, Seoul, Korea

e-mail: Jaebum50@hanmail.net

J. Kim

Cyber Secretariat of the Forum for East Asia-Latin America Co-operation, Seoul, Korea 


\section{JEL Classification F55}

\section{Introduction}

This paper aims to identify the North Korean factor in the context of East Asian regional security and propose ways to cope with it effectively with a view to promoting regional security and integration. With the broader theme of the conference, "East Asian Regional Integration and the Role of the United States", in mind, the paper intends to find an appropriate approach to enhancing regional security and integration as well as national unification. The analyses and recommendations focus more on contemporary issues and future prospects in the region as closely linked to their dynamics involving extra-regional powers.

\section{East Asian Regional Security}

If the East Asian region includes Oceania, it extends from the Russian Far East to New Zealand and comprises about 2.2 billion inhabitants in 31 states. As compared to other "Third World" areas, this region has enjoyed relative peace for the last 37 years, since the end of the Vietnam War. On the other hand, a variety of multilateral endeavours to institutionalize some sort of regional security regime ${ }^{1}$ have neither borne tangible fruit to date nor offered a promising vision for building a durable peace in the foreseeable future. Indeed, they have been derided as so many "talk shops".

To make things more complicated, the major powers involved in the region have become further subject to a variety of controversies. Suspicious eyes have been cast on China's advances in modern science and technology, its growing investment in dual-use research and development, a rapid increase in defence spending, and a stronger assertion of territorial as well as maritime rights. Its acquiescence or condonation of military technology outflows and policy to repatriate refugees back to North Korea have been protested. Observations diverge on the Japanese government's attempt to amend the peacekeeping operation co-operation law, revision of the basic atomic energy law, planned naturalization (purchase) of Diaoyu (Senkaku) Islands, and aborted pacts for closer military co-operation with South Korea. ${ }^{2}$ The Russian Federation is ramping up its "Look East" policy to the extent that the possibility of moving its capital to Asia is being considered seriously. The rebalancing policy of the United States under the slogan of "Pivot to Asia" causes contending repercussions from diverse powers.

\footnotetext{
${ }^{1}$ East Asian regional security issues are discussed in such organizations as ASEAN Regional Forum (ARF), Council for Security Cooperation in the Asia Pacific (CSCAP), East Asian Summit (EAS), ASEAN+3, Shangri-La Dialogue, to name a few.

2 Owing to public resentment in South Korea, the Japanese and ROK governments had to suspend their plan to conclude a General Security of Military Information Agreement (GSOMIA) and military Acquisition and Cross-Servicing Agreement (ACSA).
} 
No one wants to believe, of course, that there might be a devastating military clash or escalation of conflicts among the major powers in this region. China clearly identifies religious extremism, ethnic separatism, and international terrorism as major potential threats, and these are the most imminent dangers to the security of the other East Asian states as well. In addition, the proliferation of weapons of mass destruction and their delivery systems has emerged as a major concern globally since the 9/11 terrorist attacks in the United States. As a result, the North Korean factor calls for urgent regional as well as global attention.

\section{North Korean Factor}

The most critical problem caused by the North Korean factor in East Asian regional security is that the North stays mindful of two realities: (1) the other five participants in the six-party process share a common interest in denuclearizing the Korean Peninsula, and (2) all the six object to Pyongyang's sudden collapse. When the death of Kim Jong Il was announced on 19 December 2011, for example, all the parties concerned expressed condolences and hopes for an early stabilization of the situation; in other words, a smooth transfer of power in North Korea. This is the very reason that Pyongyang's brinkmanship or crisis diplomacy works; it appears to be a suicidal menace with nothing to lose.

Sharing borders with South Korea, China, and Russia, the North is determined to capitalize on its strategic location for its own survival. It remains hypersensitive to foreign influence on its security concerns and its intent on playing off the foreign powers against each other. In accordance with North Korea's weltanschauung, the alleged US antagonistic policy is the single most important source of all the difficulties it suffers. But it also calls the United States the only country that can help solve the North's problems. The United States, however, has repeatedly clarified that its condolence message on the occasion of Kim Jong Il's demise was not directed to the North Korean regime but to its people.

North Korea's persistent quest for nuclear weapons and long-range missiles stems from the political success and economic prosperity in South Korea, which are crucial detriments to the Northern regime's legitimacy. Pyongyang, therefore, seems to continue to pursue its objective of taking Seoul hostage through its nuclear and missile programmes. Making enemies of the United States and Japan, the North pressures Seoul with provocative actions to attract broader attention and extract aid from the international community. It is a paradox that the North also constantly pursues friendship with the United States as its ultimate goal. KWP International Secretary Kim Yong Il recently stated that the DPRK would not need its nuclear arsenal if the United States extended a nuclear umbrella to North Korea. This ulterior motive was revealed most prominently when DPRK Vice Foreign Minister Kim Gye Gwan enquired of his US counterparts in New York in March 2007 if Washington had any intention to utilize Pyongyang for the former's strategic advantage.

The six-party talks have proved ineffectual, so a new approach is needed in order to engage North Korea as a regional security partner. In so doing, major powers 
have to keep in mind several critical elements with the lessons learned from negotiations they have already conducted with the DPRK:

1. North Korea always claims that it is an independent and sovereign state and that the juche ideology dictates it to make each and every decision without outside interference.

2. The DPRK does not hesitate to resort to brinkmanship in negotiations to frontload minor concessions and backload major ones.

3. The North is one of the few countries existing today where the military often overrides the decisions of the government, and the party can override those of the military.

4. China is the only country that can exercise influence over North Korea with its party-to-party and military-to-military connections. While the international community expects that China would exercise its influence to dissuade North Korea from its provocative behavior, China responds that its leverage over the North is far more limited than is believed. China wants to treat the DPRK as a state with which it maintains normal diplomatic relations, whereas the North claims it occupies a unique strategic position in Northeast Asia, enjoying the historical and ideological bond of ties with China. Kim Jong Un is expected to pay a visit shortly to Beijing and other areas in China including Jiangsu Province.

5. In building regional security, Pyongyang's constructive capacity is limited, but its de facto veto power is effective.

6. North Korean veteran negotiators keep their positions for decades but face off with counterparts elsewhere whose terms of office are usually less than 2 years. Yet the North has a free hand to change its negotiators whenever it needs to manipulate and maneuver the results of negotiations in its own favour.

7. North Korea avoids permanent mechanisms and cumulative agreements that could build durable regional security and stability regimes. It makes no bones about suspending all kinds of bilateral or multilateral talks whenever it deems itself in a disadvantageous position.

8. The other five participants in the six-party talks share an interest in a denuclearized Korean Peninsula, while the North maintains a virtually opposite position. Nonetheless, the other five also have differing positions and interests despite their agreement on the overarching denuclerization goal, and Pyongyang is apt at playing off the five against one another.

9. Sanctions against the North do not normally bring their intended results but usually backfire.

10. While continuing the policies of his father and grandfather, Kim Jong Un hints at wanting to improve the welfare of ordinary North Koreans. Western observers interpret the dismissal of a military heavyweight, Vice Marshal Ri Yong Ho, and his cohorts ${ }^{3}$ as a victory of civilian-rather than party-leaders such as Jang Song Taek, Kim Jong Un's uncle-in-law, and a handful of figures

\footnotetext{
${ }^{3}$ A series of gradual liquidation proceeded from Ri Je Gang, party organizer, in May 2010, to Ryu Gyong, security apparatchik, in late 2011; and to U Dong Chuk, security apparatchik, most lately.
} 
around him ${ }^{4}$ over the military as a result of an internal power struggle, which allows cautious optimism for civilian — not party—control of state affairs. The most important is that functions of the cabinet have been reinforced to gain more weight over economic issues.

The debut of First Lady Ri Sol Ju as well as a series of unprecedentedly open and frequent appearances of Kim Jong Un in public augur well for a change in the course at least in style. All in all, it may be fair to predict a new layer on top of the injunctive reigns of Kim's father and grandfather. Just as the military-first policy was pursued on top of - not differentiated from-the juche ideology, the new regime may determine that its own type of opening and reform can be added to the on-going pursuit of nuclear warheads mounted on ICBMs.

An eye-opening phenomenon which had already started while Kim Jong Il was alive is that the regime is serious about learning the market economics by having its bureaucrats trained in foreign countries such as Vietnam, Singapore, Canada, and Nordic nations. In China alone, North Korean training and education centres are functioning in Dandong, Dalian, Shenyang, and Changchun.

Markets thrive not only within the country but also in bordering areas with China. A free market is open across the border from Hunchun, and foreign trade has been legalized. Foreign currencies such as US dollars, euros, and renminbi are openly circulating under a fluctuating exchange rate system. North Korea has promulgated seven new laws governing foreign direct investment over the last seven years. Capital inducements are in place and joint ventures have been formed to cover extended distribution networks.

For the reasons above, closer co-operation is needed more than ever for the states in the region to promote security and stability, not only among themselves but also along with outside powers to the east and west. Dynamic interactions with India, Pakistan, the United States, and the European Union, among others, will grow more vital for East Asian regional security.

\section{Regional Integration and National Unification}

China has not been very successful in dissipating the security concerns of the countries beyond its eastern border, including South Korea, Japan, and the United States. China's role as chair of the six-party process has given rise to an enervating sense that these countries are being indefinitely pulled around by North Korea. The North seems to aim at some sort of "butterfly effect" whereby its minor actions can result in significant consequences regionally and sometimes even globally. North Korea's provocative stratagems and actions run counter to the interests of the great powers, which definitely prefer maintaining the status quo. Those interests can be best served by working for East Asian regional integration and the national unification of both China and Korea at the same time.

\footnotetext{
${ }^{4}$ Those who are classified as maintaining long-term intimacy with Jang are Choe Ryong Hae, general political director; Ji Jae Ryong, ambassador to China; Mun Gyong Dok, party secretary; Ri Yong Su, party director for workers' organizations; and Pak Myong Chol, sports minister.
} 
It may be quite natural that the national interest of those nations which are disgruntled with the present state of affairs lies in nostalgia for the status quo ante. Then the question matters of what particular point of time could best satisfy the security needs of the majority. Against this backdrop, it is growing more evident that the future of East Asian regional security will be determined by Sino-American co-operation as the so-called G-2 will not be able to avoid their overwhelming role as the main architects of regional security. The 4th US-China Strategic and Economic Dialogue $(S \& E D)^{5}$ held in Beijing on 3 and 4 May 2012, yielded agreements in 67 areas of bilateral co-operation. Yet the G-2 do not seem to agree on a kind of new order that could best entertain the future security needs of a variety of nations in this region.

Ultimately, integration and eventual unification of North and South Korea will contribute to resolving the security dilemma and bringing about peace and stability in East Asia. Korean unification needs three conditions: First, the South Koreans have to build a consensus among themselves that unification is necessary and desirable and that the boons from unification will by far surpass the costs. Second, the North Korean people must choose peaceful and democratic unification. Third, the major powers surrounding the Korean Peninsula must agree that Korean unification is conducive to strengthening the peace and security of the region.

Just as German unification was promoted as part of European integration, Korean unification can best be pursued within the framework of Northeast Asian integration. The PRC-Japan-ROK summits ${ }^{6}$ can be the principal moving force in this endeavour. (Some ways to materialize it will be elaborated on in a later section of this paper.) In this way, progress in regional integration will give impetus to Korean unification processes. It is up to South Korea to play a trouble-shooting role in helping the North escape its security dilemma. For this reason, no workable alternative to the "sunshine policy" seem to exist among all the North Korea policies pursued up to the present.

The participating governments in the Tumen River Area Development Programme extended its jurisdiction in 2005 to China's three northeast provinces, Inner Mongolia, the North Korean city of Chongjin, Russia's Maritime Province, and South Korea's eastern seacoast. China's Chang-Ji-Tu Plan, announced in October 2009, undertook in December 2010 to invest US\$2 billion in the Rason Special Economic Zone. A smaller but more effective project was the RajinKhasan railway reconstruction: a trial train run was made in October 2011. As these projects are least influenced by the state of tensions arousing from the North Korean nuclear and/or missile conundrum, their opening to induce the participation of South Korea and Japan will make great contributions to regional integration.

\footnotetext{
5 The first S\&ED was held in Washington, DC on 27-28 July 2009 at the deputy prime minister level. The second S\&ED was held in Beijing at the ministerial level. The third S\&ED was held in Washington, DC on 24-25 May 2011 and the first Strategic and Security Dialogue was held at the same time.

6 The 1st summit was held in Fukuoka in December 2008, the 2nd in Beijing in October 2009, the 3rd in Jeju in May 2010, the 4th in Tokyo in May 2011, and the 5th in Beijing in May 2012.
} 


\section{Realignment of the Regional Security Framework}

The hub-and-spokes alliance structure between several East Asian states and the United States has survived the test of time and still remains the mainstay of collective security arrangements. The Nixon Doctrine has brought far-reaching effects beyond the Cold War era by enabling China to occupy a P-5 seat and concentrate on its internal stability and economic development while maintaining the status quo in East Asia. North Korea's security was guaranteed in particular by dint of US forces in the South, the ROK-US mutual defence treaty, and creation of the Combined Forces Command, all of which effectively prevented the two Koreas from escalating conflicts on the Korean Peninsula. By extension, China has decisively benefited from the functioning of such a structure.

In the light of the phenomenal transformation which has occurred so far in the overall security environment, the states in the region need to devise a realignment of their security arrangements. In so doing, the following steps need to be considered:

1. As the ongoing attempts to revive the long-stalled six-party talks have proved futile, the players in this protracted game must find an alternative way to address and redress their current issues. Each party has to talk directly to North Korea to improve their substantive relationships with the North. Even though a new multilateral process may be contrived, it should always be complemented by bilateral diplomacy between each participant and Pyongyang.

2. The parties concerned should be free from the illusion that trust must be built first with North Korea in order to attain tangible results from negotiations. On the contrary, trust may be built on the outcome of negotiations conducted in a block-building style. Economic co-operation is likely to create productive and sustainable relationships while political breakthroughs are extremely difficult to make and implement. Any meaningful agreement on confidence building measures, military confidence building measures, and others of that kind must wait until some concrete results are in place from economic interactions.

3. The vicious circle of provocations-sanctions in relations with the North has to be contained and limited to the turf of international organizations. The parties concerned can learn and practice the wisdom from a Korean proverb: "the farther the remaining journey, the more circuitous road one has to take" or "the more urgent the matter, the longer time one must take". The stakeholders in a nuclear- and missile-free Korean Peninsula should engage in working with North Korea on other issues for the time being. This way will ultimately cost less and take a shorter time to solve nuclear and missile issues, while such international organizations as the UN, P-5, IAEA, ASEAN +3, EU, and G-8 can join in the process either directly or behind the scenes. Such multilateral measures as the Finance Security Initiative should be effective if international financial organizations take charge of them.

4. A balance has to be maintained between inducements and disincentives in negotiating with the reclusive regime. One objective of North Korean provocations is to attract the attention of the world community and especially of the United States. From the North Korean perspective, the Obama 
administration's strategic patience means strategic negligence. The US government has made it clear that it would not buy the same horse twice or compensate the North for halting bad behavior. Unfortunately, no compensation or aid can offer a value equal to Pyongyang's nuclear weapon and missile programmes.

These elements may open a new window of opportunity for the following course of action by the international community in its approach to the North Korean factor during this opportune period of leadership change in almost all the countries concerned with regional security throughout 2012 and 2013:

1. Even as the United States has outsourced the North Korean nuclear issue to China as chair of the six-party process, the Russian Federation should be encouraged to play a more active part in coping with Pyongyang's nuclear and missile programmes. As far as nuclear and missile capabilities are concerned, the G-2 are Russia and the United States. The Russians have their own bureaucratic memory: negotiators of the former Soviet Union were known to have been fed up with their North Korean counterparts because of the latter's negotiating patterns of brinkmanship, one-upmanship, buck-passing, endless recycling of the same issues, and pseudo-negotiations. The origins of North Korean nuclear and missile technologies are in the former Soviet Union, and the North's first-generation scientists were trained there.

When it comes to nuclear and missile issues, one of the numerous differences between North Korea and Iran is that the former's destitution requires foreign military sales. Therefore, President Putin may try to persuade North Korea to sell each part of its nuclear fuel cycle and long-range missiles systems. A sufficient amount of uranium ore, enriched uranium, and separated plutonium, no matter whether they are weapons-grade or not, could be transferred from North Korea to participants in the G-8 Global Partnership for peaceful purposes. In the meantime, China, South Korea, Japan, and the United States could draw back from their grappling with the North Korean nuclear and missile puzzles to focus on discussions with Pyongyang about ways and means of improving their bilateral relations and about economic development plans for the North.

The actual implementation of this framework might even be entrusted to the private sector. The existing North Korean nuclear and missile programmes should be frozen and inspected while conditions are negotiated for quality control and payments. A suitable example is the Russian Research Reactor Fuel Return programme run by the Center for Energy and Security Studies in Moscow. The programme is a unique trilateral endeavor by Russia, the United States, and the IAEA to remove highly-enriched uranium from third countries to Russia.

If this new paradigm advanced smoothly, North Korea's nuclear and missile programmes would be transformed to serve as a vehicle for incorporating the Stalinist state into the global market economy and thereby onto a course of opening and reform. Then the world could expect that North Korea would start moving away from its self-imposed isolation, become a responsible member of the international community, respect human rights, and uphold the rule of law in the long run. 
Whatever project may be in place to crystallize this vision, it will have to be implemented by multinational consortia. In retrospect, it must be remembered that the first Putin administration withdrew in the mid-1990s from a number of peace initiatives launched by its predecessor on the grounds that they were commercially less viable than first estimated. More recently, in 2011, the Russian government proposed a package to supply energy to South Korea by pipeline and grid to be constructed through North Korea, with the expectation that South Korea would be a more comfortable buyer than most countries in Western Europe and the Commonwealth of Independent States. Officials from the DPRK Ministry of Crude Oil Industry, however, responded to a delegation from Russia's Gazprom visiting Pyongyang in early July 2011 by saying that they were only interested in how much would be paid for the installation and use of a trans-Korean pipeline. When the project to construct two light water reactors was carried on by the Korean Peninsula Energy Development Organization in the mid-1990s at a site the former Soviet Union had chosen for a similar project, the DPRK was keenly intent on making money from a variety of subprojects flowing from it.

2. Such countries as Myanmar should be mobilized as agents to turn their role from military co-operation with North Korea into one of exporting their opening and reform processes to Pyongyang. President Lee Myung-bak recently visited Myanmar as the first South Korean leader to do so in 29 years. In a meeting with President Thein Sein, Lee pledged to support democratization and market opening. Lee also urged the Myanmar government to cease arms deals with North Korea. It is hoped that Myanmar will not only refrain from military co-operation with North Korea, including in the nuclear field, but also show the North the advantages of domestic reforms and opening to the rest of the world.

3. All the powers, either great or small, are well aware that regional security cannot be guaranteed or promoted by violence, but they also know that peaceful diplomatic methods used to date have been ineffectual and shown no signs of anything but more procrastination. As a last resort, what they have to attempt is to promote security with commercial overtones. North Korea aims at attaining its security with the US taxpayers' money. Its demand for a peace treaty-and now even a nuclear umbrella-would require approval by the US Congress. But the United Sates is neither able nor willing to provide that money. The Clinton administration did not sign a treaty, just the Geneva "Agreed Framework", with Pyongyang in 1994 to circumvent the requirements for congressional approval for ratification. At the later stages of implementation, however, each step of appropriations for the supply of heavy fuel oil to North Korea was scrutinized by the Congress. The administration later staged fundraising campaigns among the KEDO member states and nonmembers around the world to meet its obligation for the supply of HFO, but ended up being scorned as engaging in a "nickel-and-dime diplomacy", i.e., diplomacy with hidden continuing expenses that, over time, added up to a large amount.

Even within the framework of "action for action" agreement, "who first" matters at each step of implementation. Suppose the United States agreed that it is more responsible than North Korea for the latter's insecurity and offered incentives 
attractive enough to accept. The North would then demand the repayment of its "sunk investments" poured into the on-going nuclear and missile programmes. The regional security framework, therefore, needs to be realigned in such a way that all the parties concerned may engage in some sort of lucrative and remunerative ventures involving the least possible investment for the greatest returns. No one, however, would like to invest a dime unless their mercenary motives could come to fruition sooner or later.

\section{Strengthening and Expanding Trilateral Co-Operation}

As a matter of fact, it may be impossible to make everybody happy in such a way that the economic and commercial interests of each stakeholder could be attended to, but it seems quite realistic to acknowledge Pyongyang's paranoia by buying up each component of its nuclear and missile programmes. Offers of nutrition assistance or energy compensation will never work as an equivalent exchange for nuclear and missile programmes for the secretive regime's survival. Even if the North's nuclear and missile problems are resolved, the international community will have to grapple with other issues, most obviously cyber warfare and chemical weapons. So the parties concerned have to prepare themselves to corner the market in all kinds of dual-use goods the DPRK may produce.

While buying up those components, the regional powers have to accelerate the pace of integration. The logical start point seems to be the creation of an organization for nuclear co-operation in Northeast Asia, as the origin of the European Union can be traced back to the birth of Euratom as early as in 1957. The Trilateral Cooperation Secretariat of the PRC, Japan, and the ROK was inaugurated in Seoul in September 2011 and is still collecting ideas for projects it will engage in. Just as Euratom worked for European integration, the three Northeast Asian states can strengthen nuclear co-operation with a view to expanding that integration to other fields.

During the ASEAN Regional Forum meeting in Phnom Penh on 12 July 2012, Foreign Minister Pak Ui Chun stated that North Korea would "continue to explore and utilize outer space and to develop nuclear energy for peaceful purposes" through construction of light-water reactors. Regardless of the truthfulness or trustworthiness of this statement, China, Japan, and South Korea have to respond to it by organizing a body to promote nuclear and space co-operation in Northeast Asia and welcome the DPRK as a member. This will open a channel to oversee nuclear safety and security as well as the civilian use of rocket technology in the North.

The negotiations for a PRC-Japan-ROK free trade agreement started after a joint study was completed on 16 December 2011. The leaders of the three countries agreed at their 5th summit meeting in Beijing in May 2012 to conclude such an FTA at an early date. They also signed there a trilateral agreement on investment guarantee. A trilateral free trade area can bring about far-reaching effects on the pace of regional integration, which North Korea can eventually join. For instance, the goods manufactured in the special economic zones of Kaesong, Wihwa-do, 
Hwanggumpyong, Rason, and other such zones to be established in North Korea could be exported as Korean-origin products to third countries, especially the United States, North American Free Trade Area, and Trans-Pacific Partnership.

The PRC-ROK bilateral FTA negotiations are also underway in parallel with those for a CJKFTA, which North Korea may join as well when conditions are ripe. China has long advised Pyongyang to follow the Chinese model of economic opening and reforms whereas the latter repudiates this advice while insisting on transforming itself in its own way and at its own pace. Japanese media has recently had it that the Hwanggumpyong industrial complex project had been suspended since June 2012 as differences in views were expressed by North Korea and China in conditions of investment. It reminds of the suspension of the Seoul-Shinuiju railway by China's disapproval of the creation of the Shinuiju Special Administrative Region. No matter whether the reclusive regime adopts a model from China, Vietnam, Myanmar, or whatever country, it seems to be destined to be incorporated into an irresistible trend of marketization and integration in the long run.

\section{Conclusion}

As explained above, it may be fair to conclude that a way to achieve East Asian integration while harnessing the US role and engaging in the North Korean factor in regional security is to be concentrated on three directions: (1) The international community organizes and operates a mechanism to purchase each component of the North Korean nuclear and missile programmes. (2) All the stakeholders of East Asian regional security and integration co-operate in a reunification process of both China and Korea at the same time within a broader framework of Northeast Asian sub-regional integration. (3) Northeast Asian states organize and operate a cooperative body for nuclear safety and security with a view to broadening its scope of integration to other fields.

In the final analysis, the regional security could be better promoted by seeking synergy effects of regional integration and Korean unification. As regional integration progresses so does national unification and vice versa. Each and every problem has a solution if its stakeholders approach it in a broader context, with farther-sighted visions, and in such a way as to exchange their positions with one another. More judicious prioritization of issues is required for each stakeholder. 